\title{
Evaluation of protein fractionation and ruminal and intestinal digestibility of corn milling co-products
}

\author{
J. M. Kelzer, ${ }^{*}$ P. J. Kononoff, ${ }^{* 1}$ L. O. Tedeschi,† T. C. Jenkins, $\ddagger$ K. Karges,§ and M. L. Gibson§ \\ *Department of Animal Science, University of Nebraska, Lincoln 68583 \\ †Department of Animal Science, Texas A\&M University, College Station 77843-2471 \\ ‡Department of Animal and Veterinary Sciences, Clemson University, Clemson 29634, SC \\ §Dakota Gold Research Association, Sioux Falls, SD 57104
}

\section{ABSTRACT}

Novel corn milling co-products developed from technological advancements in ethanol production vary widely in chemical composition and nutrient availability. The objectives of this study were to characterize feed protein fractions and evaluate differences in rumen-undegradable protein (RUP) and its digestible fraction (dRUP), amino acid concentration, and in vitro gas production of 7 corn milling co-products. The crude protein (CP; $\%$ of dry matter) of co-products was 12.7 for germ, 26.9 for dried distillers grains plus solubles that had no heat exposure before fermentation (DDGS1), 45.4 for highprotein dried distillers grains (HPDDG), 12.7 for bran, 30.2 for wet distillers grains plus solubles (WDGS), 23.1 for wet corn gluten feed (WCGF), and 26.0 for dried distillers grains plus solubles that had heat exposure before fermentation (DDGS2). Two ruminally and duodenally fistulated Holstein steers weighing $663 \pm 24$ $\mathrm{kg}$ were used to determine RUP and dRUP with the in situ and mobile bag techniques. Samples of each feed were ruminally incubated for $16 \mathrm{~h}$, and mobile bags were exposed to simulated abomasal digestion before insertion into the duodenum and subsequent collection in the feces. Protein fractions $\mathrm{A}, \mathrm{B}_{1}, \mathrm{~B}_{2}, \mathrm{~B}_{3}$, and $\mathrm{C}$ were characterized as follows ( $\% \mathrm{CP}$ ): germ $=30.0,15.0$, 38.1, 13.5, 3.4; DDGS1 = 17.0, 7.0, 67.0, 4.8, 4.2; HP$\mathrm{DDG}=7.4,0.6,82.4,8.8,0.8 ;$ bran $=33.5,4.0,54.3$, $6.0,2.2 ;$ WDGS $=18.6,2.4,53.1,11.0,14.9 ; \mathrm{WCGF}=$ $36.6,15.9,33.2,10.1,4.1$; and DDGS2 $=17.9,2.1,41.1$, 11.1, 27.9. The proportions of RUP and dRUP were different and are reported as follows (\% CP): DDGS2 = 56.3, 91.9; HPDDG = 55.2, 97.7; WDGS = 44.7, 93.1; DDGS1 $=33.2,92.1 ;$ bran $=20.7,65.8 ;$ germ $=16.5$, 66.8 ; and $\mathrm{WCGF}=11.5,51.1$. The concentrations of Lys and Met in the RUP were different and are listed as follows $(\% \mathrm{CP})$ : germ $=2.9,2.0 ;$ DDGS1 $=1.9$, $2.0 ;$ HPDDG $=2.0,3.2 ;$ bran $=3.2,1.5 ;$ WDGS $=$

Received June 5, 2009.

Accepted March 1, 2010.

${ }^{1}$ Corresponding author: pkononoff $2 @ u n l . e d u$
1.9, 2.3; WCGF $=3.5,1.6$; and DDGS2 $=1.9,2.4$. In vitro gas production $(\mathrm{mL} / 48 \mathrm{~h})$ was highest for germ (52.1) followed by bran (50.1), WDGS (40.7), DDGS2 (40.1), WCGF (39.0), DDGS1 (38.6), and HPDDG (37.5). Comparison of co-products defined differences in chemical composition, protein fractionation, ruminal availability, and microbial fermentation.

Key words: protein fractionation, rumen fermentation, dairy, co-product

\section{INTRODUCTION}

Technological advancements in biorefining methods used to produce ethanol have resulted in novel coproducts, some of which are recovered before fermentation, that vary widely in chemical composition and nutrient availability (Murthy et al., 2006). Enhanced technology increases the efficiency of ethanol production by capturing more starch and using less energy during the milling process (Ponnampalam et al., 2004). In a traditional dry milling process, corn grain is heated before yeast-based fermentation and the subsequent distillation that separates ethanol from whole stillage. This stillage separated from wet grains is evaporated to become condensed corn distillers solubles that may be added back to wet grains, which may then be dried to produce the common feedstuff dried distillers grains with solubles (DDGS). Exposure to high temperatures during manufacturing may damage or denature a portion of the protein in DDGS (Kleinschmit et al., 2006), which may render the protein less available to the animal (Licitra et al., 1996).

Alternative technology aimed at improving ethanol yield may negatively affect nutrient availability of accompanying co-products (Ponnampalam et al., 2004; Murthy et al., 2006, 2008). One method replaces the heating and cooking steps before fermentation in the traditional dry milling process with raw starch hydrolysis (Wang et al., 2007). Proteins may be denatured by high temperatures and as a result may be less available for ruminal digestion (Russell et al., 1992; Firkins et al., 1984). Further investigation of feeds resulting from the 
new process is warranted. Another recently developed corn-ethanol production method fractionates whole corn into 3 main components: endosperm, germ, and bran (Corredor et al., 2006; Murthy et al., 2008). The endosperm is fermented through a similar dry milling process that avoids high temperatures before fermentation to yield ethanol and high-protein dried distillers grains. The germ is dried and sold as dehydrated corn germ meal.

Corn milling co-products have been successfully included in lactating dairy rations (VanBaale et al., 2001; Anderson et al., 2006; Kleinschmit et al., 2006; Kononoff et al., 2006; Janicek et al., 2007). Practically, the inclusion of corn milling co-products is often limited because the chemical composition and nutrient availability of these feeds is poorly understood or characterized. Consequently, there is a need to accurately characterize the nutrient concentration of these co-products before they can successfully be included at higher levels in dairy rations. The main objective of this study was to evaluate 7 corn milling co-products by obtaining information on the chemical composition as well as the degradability of protein in the rumen and intestine.

\section{MATERIALS AND METHODS}

All surgical and animal handling procedures were monitored and approved by the University of Nebraska Institutional Animal Care and Use Committee before conducting this research.

\section{Sample Preparation for Corn Milling Co-Products}

Individual samples of 7 corn milling co-products were received by the University of Nebraska Ruminant Nutrition Laboratory (Lincoln, NE). These samples included corn germ meal (hereafter germ), dried distillers grains plus solubles derived from dry milling that replaced heating and cooking before fermentation with raw starch hydrolysis (DDGS1), high-protein dried distillers grains derived from the fractionation process (HPDDG), bran cake produced from the fractionation process (hereafter bran), modified wet distillers grains (WDGS), wet corn gluten feed (WCGF), and dried distillers grains plus solubles produced with a traditional dry milling process (DDGS2). Each feed originated from a different ethanol plant with the exception of germ, bran, and HPDDG, which originated from the same plant.

\section{Chemical Analysis}

The WDGS and WCGF samples were freeze-dried $\left(-50^{\circ} \mathrm{C}\right)$ for $72 \mathrm{~h}$. Once completely dried, all samples were stored in a freezer $\left(-20^{\circ} \mathrm{C}\right)$ to maintain sample integrity. Coarse samples were hand ground using a marble mortar and pestle until they reached a uniform consistency. Sub-samples of all co-products were analyzed for the complete nutrient profile required for the Cornell Net Carbohydrate and Protein System (CNCPS; Fox et al., 2004) and the Cornell-Penn-Miner (CPM) dairy model (Tedeschi et al., 2008). These analyses included DM (AOAC, 2000; method 930.15), CP (AOAC, 2000; method 990.06), soluble CP (SCP; Roe and Sniffen, 1990), NPN (Licitra et al., 1996), lignin (AOAC, 2000; method 973.18D), ADF, and NDF. Both ADF and NDF were analyzed according to the procedure of Van Soest et al., (1991; without sodium sulfite) using an Ankom Fiber Analyzer (Ankom Technology, Fairport, NY). Heat stable $\alpha$-amylase (A3306, Sigma Chemical Co., St. Louis, MO) was included in the NDF and ADF procedures $(100 \mu \mathrm{L}$ per $0.50 \mathrm{~g}$ of sample). The $\mathrm{NDF}$ and ADF components were further processed for their nitrogen content (NDIN, ADIN; AOAC, 2000; method 984.13). Samples were also analyzed for ash (AOAC, 2000; method 942.05), starch (YSI 2700 Select Biochemistry Analyzer, YSI Inc., Yellow Springs, OH; Application Note 322), and sugar (Hall et al., 1999). Minerals (Ca, P, Mg, K, Na, Fe, Zn, Cu, Mn, and S) were analyzed according to Sirois et al. (1994). The chloride ion was measured using a potentiometric titrator (Brinkmann Metrohm 716 Titrino titration unit with silver electrode, Brinkmann Instruments Inc., Westbury, NY; Application Bulletin 130). Samples were also analyzed for ether extract (EE; AOAC, 2000; method 2003.05) using an automated Tecator Soxtec System HT6 (Foss North America, Eden Prairie, MN; Application note AN 301).

Physically effective fiber (peNDF) was determined on subsamples of each original co-product. Coarse subsamples were minimally ground using a marble mortar and pestle to break up pellets and clumps. Excess grinding was avoided to minimize particle shatter, which would interfere with accurate estimates of particle size distribution. Particle size distribution was determined using approximately $200 \mathrm{~g}$ (as-fed basis) per sample in duplicate according to AOAC (1996) method S319. United States Bureau of Standard (USBS) sieves \#6 $(3,350 \mu \mathrm{m}), \# 12(1,700 \mu \mathrm{m})$, and \#16 $(1,180 \mu \mathrm{m})$ were utilized to determine particle size distribution. The USBS sieves were secured to a Fritsch Analysette sieving device (model 8751, Fritsch GmbH, Idar-Oberstein, Germany). Samples were placed into the top sieve (\#6) and sieved for $5 \mathrm{~min}$. Upon completion of sieving, distribution was determined gravimetrically. Proportions of the sample retained on sieves \#6, \#12, and \#16 were composited by sample and replicate and ground through a 1-mm screen (Wiley mill, Arthur H. Thomas 
Co., Philadelphia, PA). The NDF (Van Soest et al., 1991) concentration was determined on all samples using the Ankom Fiber Analyzer (Ankom Technology). The procedure was modified to not include sodium sulfite and included heat-stable $\alpha$-amylase (A3306, Sigma Chemical Co.) at $100 \mu \mathrm{L} / 0.50 \mathrm{~g}$ of sample. Fractions were made fat free by soaking the Ankom bags in acetone for three 10-min periods before analysis for NDF. Physically effective fiber was calculated as percentage NDF (\% of DM) multiplied by percentage of particles $>1.18 \mathrm{~mm}$ (\% of DM).

\section{Protein Fractionation}

The CNCPS protein fractions $\mathrm{A}, \mathrm{B}_{1}, \mathrm{~B}_{2}, \mathrm{~B}_{3}$, and $\mathrm{C}$ were computed for the co-products according to Sniffen et al. (1992). Briefly, fraction A is equal to NPN; fraction $\mathrm{B}_{1}$ is calculated by subtracting NPN from SCP; fraction $\mathrm{B}_{2}$ is calculated as $\mathrm{CP}-\mathrm{SCP}-\mathrm{NDIN}$; fraction $\mathrm{B}_{3}$ is calculated by difference of NDIN and ADIN; and fraction $\mathrm{C}$ is equal to ADIN.

\section{In Vitro Gas Production}

Determination of in vitro gas production (IVGP) and fermentability on each co-product was conducted at Texas A\&M University (College Station) according to the method described by Pell and Schofield (1993). Feed samples were ground to pass through a 1-mm screen (Wiley mill, Arthur H. Thomas Co.), and approximately $200 \mathrm{mg}$ of each sample was inoculated with rumen fluid and media under anaerobic conditions and fermented in vitro for $48 \mathrm{~h}$. Gas production was measured continuously using a computerized system and data were fitted to the exponential model

$$
y=a \times\left[1-e^{-b \times(t-c)}\right],
$$

where $y=\operatorname{IVGP}(\mathrm{mL}), a=$ asymptote of IVGP $(\mathrm{mL}), b$ $=$ the rate of degradation $(1 / \mathrm{h}), t=$ time of incubation (h), and $c=$ lag time (h).

\section{Fatty Acid Composition}

Subsamples of the co-products were sent to Clemson University (Clemson, SC) for analysis of fatty acids by the direct transesterification procedure of Sukhija and Palmquist (1988). Fatty acids in samples were converted to methyl esters in $5 \%(\mathrm{vol} / \mathrm{vol})$ methanolic $\mathrm{HCl}$ and separated on a $30 \mathrm{~m} \times 0.25 \mathrm{~mm} \times 0.2 \mu \mathrm{m}$ film thickness SP2380 capillary column (Supelco Inc., Bellefonte, PA). The column oven was programmed from an initial temperature of $150^{\circ} \mathrm{C}$ held for $2 \mathrm{~min}$, increased at a rate of $2^{\circ} \mathrm{C}$ per min, and then held at a final temperature of $220^{\circ} \mathrm{C}$ for $10 \mathrm{~min}$. Injector and detector temperatures were maintained at $250^{\circ} \mathrm{C}$. Heptadecanoic acid was added as an internal standard to all samples. Helium was used as a carrier gas, and verification of peak identity was established by comparison of peak retention times to known standards.

\section{In Situ Bag and Mobile Bag Preparation}

Two Holstein steers weighing $663 \pm 24 \mathrm{~kg}$ and fitted with flexible ruminal and proximal duodenal cannulas were used for the in situ and mobile bag procedures. The steers were housed in a temperature-controlled room in individual pens or metabolism stalls and fed a forage-based TMR once daily at $0700 \mathrm{~h}$ at amounts equal to $2.1 \%$ of total $\mathrm{BW}$. The ration ingredient composition (\% of diet DM) included $40 \%$ alfalfa hay, $25 \%$ dry rolled corn, $15 \%$ brome hay, $10 \%$ wet corn gluten feed, $5 \%$ soybean meal, and $5 \%$ vitamin-mineral supplement. The animals consumed $11.0 \pm 1.3 \mathrm{~kg}$ of DM per day (1.7\% of total BW) and had free access to water. During in situ incubation and duodenal insertions, steers were tied in individual stalls. Between duodenal insertion periods, steers were moved from individual stalls to individual pens for $1 \mathrm{wk}$ to permit exercise. The in situ and mobile bag techniques were used to estimate the proportion of RUP and digestibility of the RUP (dRUP). For each steer, approximately $1.25 \mathrm{~g}$ of each sample was weighed into sixty 5 $\times 10 \mathrm{~cm}$ Dacron (Ankom Inc.) nylon bags (pore size of $50 \mu \mathrm{m}$ ), which were then heat-sealed using an Ankom Heat Sealer (Vanzant et al., 1998). Fifty Dacron bags each were placed into larger nylon mesh bags $(36 \times$ $42 \mathrm{~cm}$ ) that contained 2 secured $100-\mathrm{g}$ weights before rumen incubation to prevent bags from floating in the rumen mat. At 1700 h, 6 large mesh bags per steer were inserted through the rumen cannula into the ventral sac of the rumen and incubated for $16 \mathrm{~h}$ (Woods et al., 2003). The 16-h rumen incubation period was chosen to most closely simulate rumen retention time for these co-products (Kononoff et al., 2007) and, as stated by Boucher et al. (2009), is commonly used by most other published studies, allowing for accurate comparison in estimates. After rumen incubation, all bags were removed and immediately hand rinsed in cold water to cease microbial activity. Thirty of the 60 Dacron bags (hereafter rumen bags) of each feed sample per steer were immediately frozen $\left(-20^{\circ} \mathrm{C}\right)$ for later analysis. The remaining 30 Dacron bags per sample per steer (hereafter mobile bags) were used in the mobile bag procedure according to Kononoff et al. (2007). Briefly, mobile bags were incubated in a pepsin and $\mathrm{HCl}$ solution $(1 \mathrm{~g}$ of pepsin/L of $0.01 \mathrm{M} \mathrm{HCl})$ for $3 \mathrm{~h}$ in a $39^{\circ} \mathrm{C}$ water bath to simulate abomasal digestion. Following 
the pepsin/ $\mathrm{HCl}$ incubation, 10 to 12 duodenal bags $(\geq 1$ replication/sample) per steer per day were tightly rolled and inserted into the duodenum through the duodenal fistula at $1700 \mathrm{~h}$ for 4 consecutive days. One bag was inserted every 5 min to permit movement of previous bags into the intestines and avoid compaction. Mobile bags were collected in the feces when the first bags appeared (approximately $12 \mathrm{~h}$ post-insertion) until $24 \mathrm{~h}$ post-insertion. Collected bags were hand rinsed in cold water to remove fecal material and immediately frozen $\left(-20^{\circ} \mathrm{C}\right)$ until all bags were collected.

\section{$R D P, d R U P$, and Total-Tract Digestibility}

Both rumen and mobile bags were machine-washed using five 3-min cycles consisting of a 1-min wash and a 2-min spin. Bags were then rinsed in distilled water to force all remaining residues to the bottom, rolled, and dried in a $100^{\circ} \mathrm{C}$ oven for $12 \mathrm{~h}(\mathrm{AOAC}, 1996)$. Following drying, bags were removed and immediately weighed to determine residue weight. Rumen and duodenal residues of each co-product were composited by steer and analyzed for $\mathrm{N}$ using the combustion method (AOAC, 1996) in a combustion analyzer (Leco FP-528; Leco Corp., St. Joseph, MI). Average RUP, RDP, dRUP, and total-tract CP digestibility (TTCPD) were determined for each feedstuff. The TTCPD was calculated as 1 - total-tract indigestible protein. The RDP was estimated as the proportion of CP that disappeared from the Dacron bag following in situ incubation (Kononoff et al., 2007). The RUP was calculated as 100 - RDP for each feedstuff. The digestible portion of the RUP was assumed to be the percentage of the CP escaping ruminal disappearance but not recovered in the residue following intestinal incubation and was calculated as 100 - (total-tract indigestible protein $\times 100 /$ RUP) according to Kononoff et al. (2007).

\section{AA Concentration and Apparent Digestibility}

Initial feedstuff samples and in situ bag residues were analyzed for AA. Amino acids were separated [AOAC, 1996; method 982.30 E (a)], using ion-exchange chromatography with HPLC equipment (Waters, Milford, MA). A $3 \mathrm{~mm} \times 250 \mathrm{~mm}$ stainless steel, $10-\mu \mathrm{m}$ cationexchange resin Li form column was used (Pickering Laboratories, Mountain View, CA) with a flow rate of $0.3 \mathrm{~mL} / \mathrm{min}$ and a temperature of $42^{\circ} \mathrm{C}$. Fluorescence detection at wavelengths of 338 and $425 \mathrm{~nm}$ with a Waters 474 Fluorescence Detector measured derivatives of primary amines and o-phthaldialdehyde that are formed post-column. Given that Trp is destroyed by hydrolysis in the AA procedure and therefore must be analyzed separately, a modified procedure by Lewis et al. (1976) was used to quantify Trp. This method is based on converting Trp to the fluorophore norharman in a 2-step reaction involving the cyclization of Trp to a tetrahydronorharman derivative and its subsequent oxidation to norharman. Apparent total-tract digestibility was determined on each AA by determining the portion digested (subtracting the portion of the AA left over in the dRUP from the proportion of the original sample) and dividing the digested portion by the portion in the original sample.

\section{Statistical Analyses}

Data were analyzed by using MIXED procedures of SAS (version 9.1, SAS Inst. Inc., Cary, NC). Fixed model effect was feed and random effect was replication. Statistical significance for treatment effects was declared at $P \leq 0.05$, and trends were discussed at $P \leq 0.10$. The PDIFF option was used to separate and compare differences of least squares means when the $P$-value for the treatment effect was at $P \leq 0.10$. Treatment means are presented as least squares means, and the largest standard error of the mean (SEM) is reported. The linear model for these analyses is as follows:

$$
y_{i j}=\mu+\beta_{i}+\alpha_{j}+\varepsilon_{i j}
$$

where $y_{i j}$ represents observation $i j, \mu$ represents the overall mean, $\beta_{i}$ represents the random effect of replication $i$; and $\alpha_{j}$ represents the fixed effect of feed $j$. The residual term $\varepsilon_{i j}$ is assumed to be normally, independently, and identically distributed with variance $\sigma_{e}^{2}$.

\section{RESULTS}

\section{Chemical Analyses}

Chemical analysis of the 7 corn milling co-products is listed in Table 1. As expected, the CP content was highest for HPDDG (45.4\%) and lowest for bran (12.7\%). The proportion of CP that is soluble varied from $6.7 \%$ for HPDDG to $45.6 \%$ for WCGF. In addition, the ADIN in the HPDDG was lowest $(0.8 \% \mathrm{CP})$, whereas that in DDGS2 $(25.0 \% \mathrm{CP})$ was highest. Total acid production was analyzed on the wet co-products and was higher for WCGF $(7.32 \%)$ than for WDGS $(2.68 \%)$. Germ was highest $(9.2 \%)$ in sugar content and HPDDG was lowest (0.85\%). Bran (32.0\%) and germ (29.0\%) were much higher in starch content than the remaining coproducts. The NDF content of samples ranged from $21.2 \%$ for bran to $36.9 \%$ for WCGF. There was a large range in peNDF content among all co-products, and peNDF was highest for WCGF (25.9\%) and lowest for DDGS1 (1.60\%). Percentage ADF ranged from $6.6 \%$ for 
Table 1. Chemical composition (\% of DM unless otherwise noted) of 7 corn milling co-products ${ }^{1}$

\begin{tabular}{|c|c|c|c|c|c|c|c|c|c|c|c|c|c|c|}
\hline Item & \multicolumn{14}{|c|}{ Corn milling co-product ${ }^{2}$} \\
\hline DM, \% as-fed & 91.0 & 0.07 & 86.7 & 0.00 & 94.7 & 0.50 & 90.7 & 0.71 & 45.6 & 0.00 & 55.9 & 0.00 & 86.9 & 0.00 \\
\hline $\mathrm{CP}$ & 14.6 & 0.22 & 26.9 & 0.39 & 45.4 & 0.09 & 12.7 & 0.10 & 30.2 & 0.20 & 23.1 & 0.06 & 25.9 & 0.41 \\
\hline $\mathrm{SCP}^{3}$ & 40.5 & 3.13 & 21.5 & 1.36 & 6.73 & 1.39 & 35.3 & 1.17 & 21.2 & 0.34 & 45.6 & 1.59 & 16.6 & 1.76 \\
\hline $\mathrm{NFC}^{5}$ & 30.3 & 0.46 & 18.8 & 0.83 & 22.2 & 0.16 & 49.1 & 1.81 & 19.8 & 0.40 & 24.6 & 0.83 & 19.2 & 0.54 \\
\hline Acetic acid & - & - & - & - & - & - & - & - & 0.48 & 0.01 & 0.07 & 0.01 & - & - \\
\hline Propionic acid & - & - & - & - & - & - & - & - & 0.03 & 0.00 & 0.06 & 0.00 & - & - \\
\hline Butyric acid & - & - & - & - & - & - & - & - & 0.00 & 0.00 & 0.00 & 0.00 & - & - \\
\hline Total acids & - & - & - & - & - & - & - & - & 2.68 & 0.04 & 7.32 & 0.00 & - & - \\
\hline Sugar & 9.20 & 0.99 & 3.45 & 0.78 & 0.85 & 0.07 & 5.05 & 0.35 & 3.00 & 0.42 & 4.50 & 0.28 & 4.80 & 0.71 \\
\hline Ash & 5.73 & 0.03 & 7.62 & 0.47 & 4.21 & 0.37 & 4.15 & 0.03 & 5.32 & 0.24 & 6.75 & 0.34 & 6.27 & 0.18 \\
\hline Ether extract & 17.7 & 0.07 & 13.3 & 0.28 & 4.00 & 0.57 & 12.1 & 0.42 & 14.2 & 0.28 & 5.10 & 0.00 & 11.8 & 0.21 \\
\hline
\end{tabular}

${ }^{1}$ All entities except NPN and peNDF were analyzed by Dairy One Forage Laboratory, Ithaca, NY.

${ }^{2}$ Germ $=$ dehydrated corn germ meal; DDGS1 $=$ dried distillers grains plus solubles (no heating or cooking before fermentation); HPDDG $=$ high protein dried distillers grains (no solubles included); Bran = corn bran plus solubles (pelleted); WDGS = modified wet distillers grains plus solubles; WCGF = wet corn gluten feed; DDGS2 = dried distillers grains plus solubles (had heating and cooking before fermentation).

${ }^{3}$ Soluble protein.

${ }^{4} \mathrm{NPN}$ determined using the nonprotein nitrogen standard procedure from Licitra et al. (1996).

${ }^{5} \mathrm{NFC}$ calculated as $100-(\mathrm{CP}+$ ether extract + ash $+\mathrm{NDF})$.

${ }^{6}$ Physically effective NDF equals the $\%$ of DM particles $>1.18 \mathrm{~mm}$ in length $\times \%$ of NDF (Mertens, 1997).

HPDDG to $25.2 \%$ for DDGS2. Similarly, DDGS2 was higher $(10.1 \%)$ in lignin content compared with other co-products. As expected, germ was highest (17.7\%) in ether extract, whereas HPDDG was lowest (4.0\%). The mineral composition of the 7 different corn milling co-products is listed in Table 2. The $\mathrm{P}$ content varied greatly among co-products and was lowest for HPDDG $(0.35 \%)$ followed by bran (0.60\%), DDGS2 (0.86\%), WDGS $(0.87 \%)$, DDGS1 $(0.92 \%)$, germ $(1.18 \%)$, and WCGF (1.18\%). Likewise, the S content of the coproducts was highly variable and ranged from $0.15 \%$ for germ to $0.90 \%$ for DDGS1.

\section{Particle Size Distribution}

Particle size distribution for each corn milling coproduct varied widely and is listed in Table 3 . The proportion of particles $>3.35 \mathrm{~mm}$ ranged from $0.00 \%$ for HPDDG to $10.5 \%$ for bran. Likewise, HPDDG (1.45\%) had the lowest proportion of particles that measured 1.7 to $3.35 \mathrm{~mm}$, and WCGF $(36.9 \%)$ had the highest proportion. The percentage of particles measuring 1.18 to $1.7 \mathrm{~mm}$ was lowest for DDGS1 (3.51\%) followed by HPDDG (10.6\%), WDGS (12.3\%), DDGS2 (15.1\%), WCGF $(18.6 \%)$, germ $(18.9 \%)$, and bran
(19.4\%). In addition, the proportion of particles $<1.18$ mm was highest for DDGS1 (94.2\%) followed by HPDDG (87.8\%), WDGS (82.2\%), DDGS2 $(60.1 \%)$, germ (40.4\%), WCGF (39.3\%), and bran (37.1\%).

\section{Fatty Acid Concentration}

The fatty acid (FA) profile of each sample is listed in Table 4. The highest concentration of total FA (TFA) was observed in germ $(14.3 \%)$ whereas the lowest was in WCGF (4.9\%). Concentration of palmitic acid (C16:0) ranged from $11.5 \%$ of TFA for germ to $19.3 \%$ of TFA for WCGF. Stearic acid (C18:0) concentration was typically low and averaged $2.31 \pm 0.43 \%$ of TFA across co-products. The concentration of oleic acid (C18:1 cis) was also similar across co-products and averaged 24.0 $\pm 2.05 \%$ of TFA. As expected, the concentration of linoleic acid (C18:2) was high for all co-products and ranged from $48.3 \%$ of TFA in WCGF to $54.2 \%$ of TFA in WDGS.

\section{Protein Fractionation}

Protein fractions for each co-product are listed in Table 5. The A fraction protein was highest in WCGF 
Table 2. Mineral composition (DM basis) of 7 corn milling co-products

\begin{tabular}{|c|c|c|c|c|c|c|c|c|c|c|c|c|c|c|}
\hline Mineral & \multicolumn{14}{|c|}{ Corn milling co-product ${ }^{1}$} \\
\hline $\mathrm{Ca}, \%$ & 0.01 & 0.00 & 0.05 & 0.00 & 0.02 & 0.00 & 0.03 & 0.00 & 0.03 & 0.00 & 0.03 & 0.00 & 0.34 & 0.04 \\
\hline P, $\%$ & 1.18 & 0.02 & 0.92 & 0.01 & 0.35 & 0.00 & 0.60 & 0.01 & 0.87 & 0.01 & 1.18 & 0.00 & 0.86 & 0.01 \\
\hline $\mathrm{Mg}, \%$ & 0.46 & 0.01 & 0.38 & 0.00 & 0.08 & 0.00 & 0.26 & 0.00 & 0.32 & 0.01 & 0.48 & 0.01 & 0.39 & 0.03 \\
\hline $\mathrm{Na}, \%$ & 0.00 & 0.00 & 0.16 & 0.00 & 0.16 & 0.00 & 0.37 & 0.00 & 0.27 & 0.01 & 0.28 & 0.00 & 0.48 & 0.04 \\
\hline $\mathrm{Cl}, \%$ & 0.12 & 0.01 & 0.19 & 0.01 & 0.10 & 0.02 & 0.21 & 0.02 & 0.21 & 0.01 & 0.21 & 0.00 & 0.30 & 0.02 \\
\hline $\mathrm{Fe}, \mathrm{mg} / \mathrm{kg}$ & 72.5 & 0.71 & 89.5 & 2.12 & 47.5 & 0.71 & 90.0 & 8.49 & 116.0 & 3.54 & 95.5 & 20.5 & 150.0 & 7.78 \\
\hline $\mathrm{Zn}, \mathrm{mg} / \mathrm{kg}$ & 90.0 & 9.90 & 101.0 & 0.71 & 22.0 & 0.00 & 233.0 & 1.41 & 62.5 & 0.71 & 106.0 & 24.8 & 119.0 & 9.19 \\
\hline $\mathrm{Cu}, \mathrm{mg} / \mathrm{kg}$ & 5.00 & 0.00 & 5.00 & 0.00 & 3.00 & 1.41 & 3.50 & 0.71 & 6.00 & 1.41 & 3.50 & 2.12 & 12.0 & 0.00 \\
\hline $\mathrm{Mn}, \mathrm{mg} / \mathrm{kg}$ & 18.0 & 0.00 & 16.0 & 0.00 & 4.00 & 0.00 & 13.0 & 0.00 & 16.5 & 0.71 & 23.5 & 0.71 & 123.0 & 23.33 \\
\hline
\end{tabular}

${ }^{1}$ Germ $=$ dehydrated corn germ meal; DDGS1 = dried distillers grains plus solubles (no heating or cooking before fermentation); HPDDG $=$ high protein dried distillers grains (no solubles included); Bran = corn bran plus solubles (pelleted); WDGS = modified wet distillers grains plus solubles; WCGF = wet corn gluten feed; DDGS2 = dried distillers grains plus solubles (had heating and cooking before fermentation).

$(36.6 \%)$ followed by bran $(33.5 \%)$, germ $(30.0 \%)$, WDGS (18.6\%), DDGS2 (17.9\%), DDGS1 (17.0\%), and HPDDG $(7.4 \%)$. Likewise, fraction $\mathrm{B}_{1}$ was highest in WCGF $(15.9 \%)$. The proportions of fraction $\mathrm{B}_{2}$ protein in HPDDG $(82.4 \%)$ and DDGS1 (67.0\%) were much higher than in bran $(54.3 \%)$, WDGS $(53.1 \%)$, DDGS2 (41.1\%), germ (38.1\%), and WCGF (33.2\%). Fraction $\mathrm{B}_{3}$ was more similar among all co-products and ranged from $4.8 \%$ of CP for DDGS1 to $13.5 \%$ of CP for germ. The protein contained in DDGS2 $(27.9 \%)$ and WDGS $(14.9 \%)$ was much higher in fraction $\mathrm{C}$ than that contained in DDGS1 (4.2\%), WCGF (4.1\%), germ (3.4\%), bran $(2.2 \%)$, and HPDDG $(0.9 \%)$.

\section{$R D P, d R U P$, and Total-Tract Degradability}

The proportions of RUP, dRUP, and TTDCP as percentage $\mathrm{CP}$ are listed in Table 5 . The co-products varied widely in proportions of RUP: it was highest for DDGS2 (56.3\%), followed by HPDDG (55.2\%), WDGS $(44.7 \%)$, DDGS1 $(33.2 \%)$, bran $(20.7 \%)$, germ $(16.5 \%)$, and WCGF (11.5\%). The digestible portion of the RUP was highest for HPDDG $(97.7 \%)$ followed by WDGS (93.1\%), DDGS1 (92.1\% CP), DDGS2 (91.9\% $\mathrm{CP})$, germ $(66.8 \% \mathrm{CP})$, bran $(65.8 \% \mathrm{CP})$, and WCGF $(51.1 \% \mathrm{CP})$. All co-products had high TTDCP (>90\% $\mathrm{CP}$ ) that ranged from $98.7 \%$ for HPDDG to $93.1 \%$ for bran.

\section{AA Concentration in Co-Products and RUP and Total-Tract Apparent AA Digestibility}

The AA concentration (\% in CP) of both the original co-products and the RUP are listed in Table 6 . The corn milling co-products were relatively low in Met and ranged from $1.12 \% \mathrm{CP}$ for DDGS2 to $3.74 \% \mathrm{CP}$ for

Table 3. Particle size distribution of 7 corn milling co-products

\begin{tabular}{|c|c|c|c|c|c|c|c|c|c|c|c|c|c|c|}
\hline Item & \multicolumn{14}{|c|}{ Corn milling co-product ${ }^{1}$} \\
\hline \multicolumn{15}{|c|}{ Particle size $^{2} \%$ retained } \\
\hline $\begin{array}{l}>3.35 \mathrm{~mm} \\
3.35-1.70 \mathrm{~mm}\end{array}$ & $\begin{array}{l}3.56 \\
36.6\end{array}$ & $\begin{array}{l}0.23 \\
0.44\end{array}$ & $\begin{array}{l}0.35 \\
1.72\end{array}$ & $\begin{array}{l}0.14 \\
0.04\end{array}$ & $\begin{array}{l}0.00 \\
1.45\end{array}$ & $\begin{array}{l}0.00 \\
0.14\end{array}$ & $\begin{array}{l}10.5 \\
32.7\end{array}$ & $\begin{array}{l}1.98 \\
1.43\end{array}$ & $\begin{array}{l}0.25 \\
5.09\end{array}$ & $\begin{array}{l}0.12 \\
0.13\end{array}$ & $\begin{array}{l}5.43 \\
36.9\end{array}$ & $\begin{array}{l}0.68 \\
0.79\end{array}$ & $\begin{array}{l}8.07 \\
16.5\end{array}$ & $\begin{array}{l}1.18 \\
0.26\end{array}$ \\
\hline
\end{tabular}

${ }^{1}$ Germ = dehydrated corn germ meal; DDGS1 = dried distillers grains plus solubles (no heating or cooking before fermentation); HPDDG $=$ high protein dried distillers grains (no solubles included); Bran = corn bran plus solubles (pelleted); WDGS = modified wet distillers grains plus solubles; WCGF = wet corn gluten feed; DDGS2 = dried distillers grains plus solubles (had heating and cooking before fermentation).

${ }^{2}$ Particle size distribution determined using United States Bureau of Standard sieves (\#6, \#12, and \#16) secured to a Fritsch Analysette sieving device (model 8751, Fritsch GmbH, Idar-Oberstein, Germany).

${ }^{3} \mathrm{NDF}$ of co-product particles $>1.18 \mathrm{~mm}$ analyzed according to Van Soest et al. (1991) using $0.5 \mathrm{~mL}$ of $\alpha$-amylase/sample and without sodium sulfite. 
Table 4. Concentration of fatty acids (FA) in 7 corn milling co-products

\begin{tabular}{|c|c|c|c|c|c|c|c|c|c|c|c|c|c|c|}
\hline FA & \multicolumn{14}{|c|}{ Corn milling co-product ${ }^{1}$} \\
\hline $\begin{array}{l}\text { Total FA, }{ }^{2} \% \text { of DM } \\
\mathrm{FA},{ }^{3} \% \text { of total FA }\end{array}$ & 14.3 & 0.11 & 11.3 & 0.11 & 6.62 & 0.05 & 7.58 & 0.07 & 12.6 & 0.08 & 4.88 & 0.05 & 8.62 & 0.05 \\
\hline C16:0 & 11.5 & 0.01 & 14.4 & 0.01 & 17.7 & 0.02 & 14.3 & 0.02 & 14.3 & 0.08 & 19.3 & 0.17 & 14.3 & 0.03 \\
\hline $\mathrm{C} 18: 2$ & 53.5 & 0.11 & 52.2 & 0.02 & 50.5 & 0.13 & 50.9 & 0.08 & 54.2 & 0.03 & 48.3 & 0.15 & 53.0 & 0.06 \\
\hline C18:3 & 1.01 & 0.01 & 1.38 & 0.02 & 1.80 & 0.01 & 1.51 & 0.01 & 1.53 & 0.00 & 2.00 & 0.01 & 1.45 & 0.00 \\
\hline Other lipid ${ }^{4}$ & 6.69 & 0.19 & 3.66 & 0.03 & 4.80 & 0.16 & 6.37 & 0.11 & 3.45 & 0.09 & 7.28 & 0.28 & 4.45 & 0.12 \\
\hline
\end{tabular}

${ }^{1}$ Germ = dehydrated corn germ meal; DDGS1 = dried distillers grains plus solubles (no heating or cooking before fermentation); HPDDG = high protein dried distillers grains (no solubles included); Bran = corn bran plus solubles (pelleted); WDGS = modified wet distillers grains plus solubles; WCGF = wet corn gluten feed; DDGS2 = dried distillers grains plus solubles (had heating and cooking before fermentation).

${ }^{2}$ As determined by the procedure of Sukhija and Palmquist (1988).

${ }^{3}$ Concentration of individual fatty acids.

${ }^{4}$ Lipid present in co-product other than those characterized in the table.

WCGF. In addition, the concentration of Lys was much higher in WCGF (8.9\%) compared with germ (4.4\%), bran (4.0\%), WDGS (2.5\%), DDGS1 (2.1\%), HPDDG (1.5\%), and DDGS2 (1.4\%). Similarly, the concentration of Leu was much higher in WCGF (17.5\%) than in the remaining co-products, which averaged $8.3 \pm$ $0.86 \%$ of CP. In some co-products, Trp was almost undetectable (0.4\% for DDGS1, HPDDG, and WDGS) compared with $1.6 \%$ for WCGF, $1.2 \%$ for germ, and $0.9 \%$ for bran.

In the RUP fraction, the AA concentration (\% of $\mathrm{CP})$ was different across co-products. The concentration of Met in the RUP was low among all co-products and ranged from $1.5 \% \mathrm{CP}$ for bran to $3.2 \% \mathrm{CP}$ for
HPDDG. The concentration of Lys was also low among co-products and varied from $1.9 \% \mathrm{CP}$ for DDGS1 to $3.5 \%$ CP for WCGF. For all co-products, Leu was relatively high in the RUP portion of the $\mathrm{CP}$ and ranged from $8.0 \% \mathrm{CP}$ for WCGF to $16.2 \% \mathrm{CP}$ for HPDDG. The concentration of Trp in the RUP followed a similar trend as was observed in the original co-products and was higher for germ $(2.5 \% \mathrm{CP})$, bran $(1.1 \% \mathrm{CP})$, and WCGF $(0.7 \%$ CP) than for DDGS1 $(0.5 \%$ CP), WDGS (0.5\% CP), DDGS2 (0.5\% CP), and HPDDG (0.4\%).

Across co-products, the apparent digestibility of each AA varied widely (Table 7). The digestibility of Met was highest for WDGS (93.1\%) followed by bran (88.9\%), DDGS1 (87.2\%), HPDDG (78.3\%), WCGF

Table 5. Protein fractions and digestibilities (\%) of 7 corn milling co-products

\begin{tabular}{|c|c|c|c|c|c|c|c|c|c|}
\hline Fraction, \% CP & \multicolumn{7}{|c|}{ Corn milling co-product ${ }^{1}$} & $\mathrm{SEM}^{2}$ & $P$-value ${ }^{3}$ \\
\hline $\bar{A}$ & $30.0^{\mathrm{a}}$ & $17.0^{\mathrm{bg}}$ & $7.42^{\mathrm{c}}$ & $33.5^{\mathrm{d}}$ & $18.6^{\mathrm{eg}}$ & $36.6^{\mathrm{f}}$ & $17.9^{\mathrm{g}}$ & 0.46 & $<0.01$ \\
\hline $\mathrm{B}_{2}$ & $38.1^{\mathrm{a}}$ & $67.0^{\mathrm{b}}$ & $82.4^{\mathrm{c}}$ & $54.3^{\mathrm{d}}$ & $53.1^{\mathrm{de}}$ & $33.2^{\mathrm{f}}$ & $41.1^{\mathrm{ag}}$ & 1.00 & $<0.01$ \\
\hline $\mathrm{B}_{3}$ & $13.5^{\mathrm{ag}}$ & $4.82^{\mathrm{bd}}$ & $8.79^{\text {cde }}$ & $5.96^{\mathrm{d}}$ & $11.0^{\mathrm{eg}}$ & $10.1^{\text {ef }}$ & $11.1^{\mathrm{cfg}}$ & 0.87 & $<0.01$ \\
\hline $\mathrm{C}$ & $3.39^{\text {adf }}$ & $4.16^{\mathrm{ab}}$ & $0.85^{\mathrm{c}}$ & $2.21^{\mathrm{cd}}$ & $14.9^{\mathrm{e}}$ & $4.13^{\text {bf }}$ & $27.9^{\mathrm{g}}$ & 0.44 & $<0.01$ \\
\hline
\end{tabular}

${ }^{\text {a-g }}$ Values in the same row with different superscripts differ $(P<0.05)$.

${ }^{1}$ Germ $=$ dehydrated corn germ meal; DDGS1 = dried distillers grains plus solubles (no heating or cooking before fermentation); HPDDG $=$ high protein dried distillers grains (no solubles included); Bran = corn bran plus solubles (pelleted); WDGS = modified wet distillers grains plus solubles; WCGF = wet corn gluten feed; DDGS2 = dried distillers grains plus solubles (had heating and cooking before fermentation).

${ }^{2}$ Highest SEM is reported.

${ }^{3}$ Main effect of the treatment: $P$-values $<0.05$ are significantly different; $P$-values $\leq 0.10$ are considered a trend.

${ }^{4}$ RUP determined using the mobile bag technique (Kononoff et al., 2007).

${ }^{5}$ Digestible portion of the RUP determined using the mobile bag technique (Kononoff et al., 2007).

${ }^{6}$ Total-tract CP digestibility determined using the mobile bag technique (Kononoff et al., 2007). 
Table 6. Concentration (\%) of AA in the original sample and RUP of corn milling co-products

\begin{tabular}{|c|c|c|c|c|c|c|c|c|c|c|c|c|c|c|}
\hline \multirow[b]{3}{*}{ Amino acid } & \multicolumn{14}{|c|}{ Corn milling co-product ${ }^{1}$} \\
\hline & \multicolumn{2}{|c|}{ Germ } & \multicolumn{2}{|c|}{ DDGS1 } & \multicolumn{2}{|c|}{ HPDDG } & \multicolumn{2}{|c|}{ Bran } & \multicolumn{2}{|c|}{ WDGS } & \multicolumn{2}{|c|}{ WCGF } & \multicolumn{2}{|c|}{ DDGS2 } \\
\hline & Mean & $\mathrm{SD}$ & Mean & $\mathrm{SD}$ & Mean & $\mathrm{SD}$ & Mean & $\mathrm{SD}$ & Mean & $\mathrm{SD}$ & Mean & $\mathrm{SD}$ & Mean & $\mathrm{SD}$ \\
\hline \multicolumn{15}{|l|}{ Sample AA } \\
\hline Methionine & 1.88 & 0.20 & 1.53 & 0.02 & 1.46 & 0.01 & 1.95 & 0.28 & 1.86 & 0.10 & 3.74 & 0.09 & 1.12 & 0.06 \\
\hline Lysine & 4.38 & 0.45 & 2.09 & 0.02 & 1.52 & 0.01 & 3.98 & 0.56 & 2.46 & 0.14 & 8.89 & 0.21 & 1.42 & 0.08 \\
\hline Isoleucine & 2.27 & 0.24 & 2.32 & 0.02 & 2.18 & 0.01 & 2.76 & 0.39 & 2.26 & 0.13 & 6.03 & 0.14 & 1.71 & 0.10 \\
\hline Valine & 3.73 & 0.39 & 3.10 & 0.03 & 2.70 & 0.01 & 4.12 & 0.58 & 3.20 & 0.18 & 9.20 & 0.22 & 2.43 & 0.14 \\
\hline Histidine & 2.63 & 0.27 & 1.84 & 0.02 & 1.48 & 0.01 & 2.72 & 0.38 & 1.84 & 0.10 & 6.25 & 0.15 & 1.36 & 0.08 \\
\hline Phenylalanine & 3.58 & 0.37 & 3.38 & 0.04 & 3.36 & 0.02 & 3.82 & 0.54 & 3.32 & 0.19 & 7.36 & 0.18 & 2.78 & 0.16 \\
\hline Tryptophan & 1.17 & 0.12 & 0.38 & 0.00 & 0.41 & 0.00 & 0.92 & 0.13 & 0.39 & 0.02 & 1.59 & 0.04 & 0.37 & 0.02 \\
\hline \multicolumn{15}{|l|}{ RUP AA } \\
\hline Isoleucine & 2.78 & 0.10 & 3.04 & 0.11 & 3.52 & 0.03 & 2.64 & 0.21 & 2.98 & 0.03 & 2.42 & 0.07 & 3.27 & 0.16 \\
\hline Valine & 3.81 & 0.07 & 3.62 & 0.20 & 4.07 & 0.07 & 3.54 & 0.23 & 3.76 & 0.03 & 3.50 & 0.03 & 4.18 & 0.15 \\
\hline Histidine & 1.69 & 0.04 & 1.70 & 0.10 & 1.84 & 0.02 & 1.70 & 0.05 & 1.80 & 0.05 & 1.82 & 0.03 & 1.99 & 0.04 \\
\hline Phenylalanine & 4.51 & 0.13 & 5.20 & 0.05 & 6.09 & 0.39 & 4.13 & 0.09 & 4.85 & 0.10 & 3.58 & 0.05 & 5.28 & 0.14 \\
\hline Tryptophan & 2.49 & 0.61 & 0.46 & 0.06 & 0.36 & 0.02 & 1.06 & 0.27 & 0.45 & 0.01 & 0.67 & 0.07 & 0.45 & 0.04 \\
\hline
\end{tabular}

${ }^{1}$ Germ $=$ dehydrated corn germ meal; DDGS1 = dried distillers grains plus solubles (no heating or cooking before fermentation); HPDDG $=$ high protein dried distillers grains (no solubles included); Bran = corn bran plus solubles (pelleted); WDGS = modified wet distillers grains plus solubles; WCGF = wet corn gluten feed; DDGS2 = dried distillers grains plus solubles (had heating and cooking before fermentation).

(75.2\%), germ (71.9\%), and DDGS2 $(62.6 \%)$. The Lys present in DDGS2 was least $(42.2 \%)$ digestible followed by that in WCGF (61.0\%), germ (65.4\%), bran $(65.3 \%)$, DDGS1 (65.5\%), HPDDG $(80.5 \%)$, and WDGS $(80.6 \%)$. Leucine appeared to be quite digestible among all co-products and ranged from $70.0 \%$ for DDGS2 to $91.2 \%$ for WDGS. In contrast, Trp seemed to have low total-tract digestibility overall but was lowest for germ (13.9\%) and highest for DDGS2 (58.5\%). Among the distillers co-products (DDGS1, HPDDG, WDGS, and DDGS2), DDGS2 appeared to have much lower total-tract digestibilities for most AA.

\section{IVGP}

Parameters that determine total gas volume produced during a 48-h fermentation period are listed in Table 8. The asymptote of IVGP was different among co-products and was much higher for germ (52.1\%) and bran (50.1\%) than for DDGS1 (38.6\%), HPDDG (37.5\%), WDGS (40.7\%), WCGF (39.0\%), and DDGS2 $(40.1 \%)$. The rate of degradation was highest for germ $(19.3 \% / \mathrm{h})$ followed by HPDDG and bran $(16.1 \% / \mathrm{h})$, DDGS1 $(14.6 \% / \mathrm{h}), \quad$ WCGF $(11.9 \% / \mathrm{h}), \quad$ DDGS2 $(10.3 \% / h)$, and WDGS $(9.1 \% / h)$. Lag time was similar across different feedstuffs.

\section{DISCUSSION}

The CNCPS assigns intestinal digestibility coefficients to all fractions, and subdivides the true protein fraction B into 3 categories based on ruminal availability (Schwab et al., 2003). The protein fractions reported for the co-products in this study are comparable to values determined by Kleinschmit et al. (2007) on 5 DDGS produced at various ethanol plants. In their study, values ranged from 5.2 to $9.8,0.1$ to $1.8,40.9$ to $51.1,22.7$ to 41.4 , and 7.5 to $23.1 \% \mathrm{CP}$ for fractions $\mathrm{A}, \mathrm{B}_{1}, \mathrm{~B}_{2}$, $\mathrm{B}_{3}$, and $\mathrm{C}$, respectively. Additionally, the authors characterized differences in ruminal CP degradability using the in situ procedure, determined intestinal digestion of RUP using pepsin and pancreatin, and measured postruminal amino acid availability on residues from a 12-h ruminal incubation of feeds. Compared with the current study, slightly higher values for RUP (59.1 to $71.7 \% \mathrm{CP}$ for DDGS and $53.6 \% \mathrm{CP}$ for wet distillers grains) and much lower values for total-tract $\mathrm{CP}$ digestibility (70.7 to $85.3 \%$ CP for DDGS and $81.9 \%$ $\mathrm{CP}$ for wet distillers grains) for various samples of distillers grains were observed. Nevertheless, the authors concluded that significant differences exist in protein degradation and digestibility among various sources of distillers grains plus solubles. 
Table 7. Total-tract apparent AA digestibilities (\%) for 7 corn milling co-products ${ }^{1}$

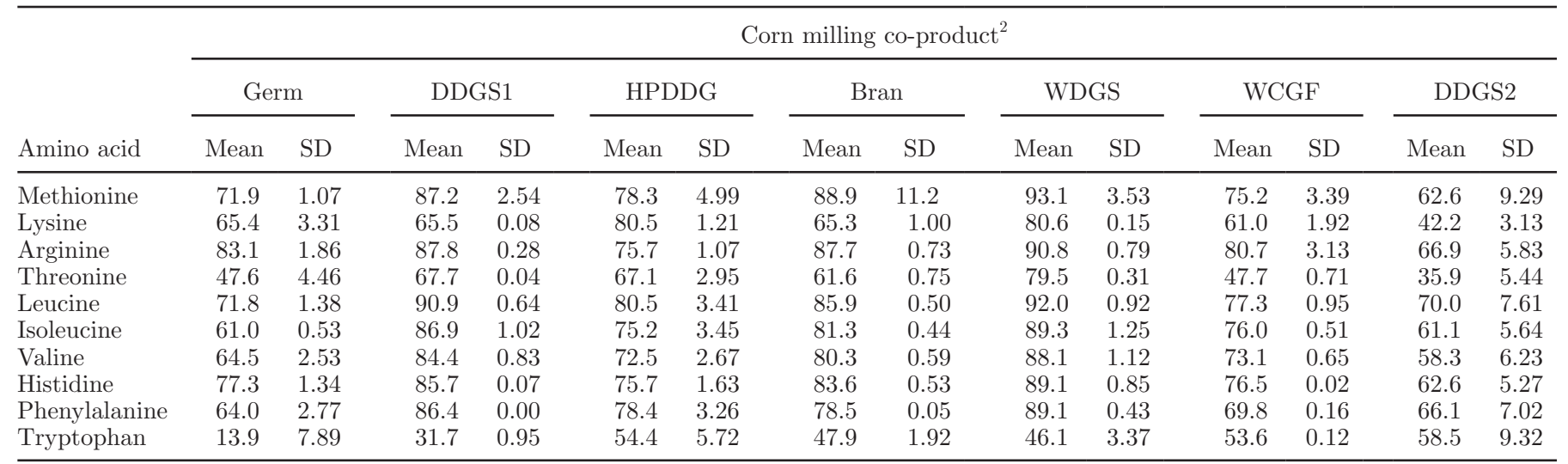

${ }^{1}$ Digestibility of AA calculated as [(\% AA in feed - \% AA in digestible RUP $) / \%$ AA in feed]. Protein fractions of RUP and digestible RUP were determined using the mobile bag technique (Kononoff et al., 2007).

${ }^{2}$ Germ = dehydrated corn germ meal; DDGS1 = dried distillers grains plus solubles (no heating or cooking before fermentation); HPDDG = high protein dried distillers grains (no solubles included); Bran = corn bran plus solubles (pelleted); WDGS = modified wet distillers grains plus solubles; WCGF = wet corn gluten feed; DDGS2 = dried distillers grains plus solubles (had heating and cooking before fermentation).

The high protein content of HPDDG was expected because the fractionation process concentrates the major components that comprise the corn kernel. Although HPDDG had the highest CP among co-products, the portion of soluble protein in HPDDG was low (6.7\%). Because soluble protein is assumed to be immediately degraded in the rumen (Sniffen et al., 1992; Schwab et al., 2003), HPDDG also had the lowest proportion of fraction A ( $0.6 \%$ of $\mathrm{CP})$ and almost the highest RUP (55.2\% of CP). The only co-product that was higher in RUP than HPDDG was DDGS2, which may be due to heat-damaged protein as indicated by its low soluble protein content $(16.6 \%$ of $\mathrm{CP})$, high ADIN content ( $25.0 \%$ of $\mathrm{CP})$, and corresponding high protein fraction C $(27.9 \%$ of CP). In addition, co-products with higher $\mathrm{C}$ fractions also had correspondingly elevated ADF contents likely caused by excessive heating (Kleinschmit et al., 2007).

Excessive heating of forages and silages increases lignin, lignin-bound N, and ADF contents (Van Soest,
1965), lowers concentration of hemicellulose (Goering et al., 1973), and decreases protein digestibility by 12 to 60\% (Bechtel et al., 1945; Miller et al., 1967; Yu and Thomas, 1975; Yu and Viera, 1977; Weiss et al., 1986). The ADIN concentration increases in heated forages, which suggests that acid-stable linkages are formed between $\mathrm{N}$ compounds and other forage constituents during the Maillard reaction (Van Soest, 1965). Proteins are denatured by high temperatures and may have lower solubility and rates of degradation in the rumen and may be unavailable for ruminal digestion (Russell et al., 1992). It has been well documented that apparent protein digestibility and animal performance decrease when animals consume heated forages (Bechtel et al., 1943; Bratzler et al., 1960; Wieringa et al., 1961; Hill and Noller, 1963; Goering et al., 1973). However, several studies have demonstrated that variable amounts of ADIN, particularly found in concentrate sources, can provide amino acids postruminally (Nakamura et al., 1994; Klopfenstein, 1996; Schwab et al., 2003). Naka-

Table 8. In vitro gas production from 48-h anaerobic fermentation of 7 corn milling co-products ${ }^{1}$

\begin{tabular}{|c|c|c|c|c|c|c|c|c|c|}
\hline \multirow[b]{2}{*}{ Item } & \multicolumn{7}{|c|}{ Corn milling co-product $^{2}$} & \multirow[b]{2}{*}{$\mathrm{SEM}^{3}$} & \multirow[b]{2}{*}{$P$-value } \\
\hline & Germ & DDGS1 & HPDDG & Bran & WDGS & WCGF & DDGS2 & & \\
\hline$b$, rate of degradation, $\% / \mathrm{h}$ & 19.3 & 14.6 & 16.1 & 16.1 & 9.10 & 11.9 & 10.3 & 0.18 & $<0.01$ \\
\hline$c$, lag time, $\mathrm{h}$ & 1.42 & 0.38 & 0.65 & 1.25 & 0.35 & 0.89 & 0.60 & 0.34 & 0.15 \\
\hline
\end{tabular}

${ }^{1}$ Gas production was measured continuously with a computerized system over a 48-h fermentation period. Data were fitted to an exponential model.

${ }^{2}$ Germ $=$ dehydrated corn germ meal; DDGS1 = dried distillers grains plus solubles (no heating or cooking before fermentation); HPDDG $=$ high protein dried distillers grains (no solubles included); Bran = corn bran plus solubles (pelleted); WDGS = modified wet distillers grains plus solubles; WCGF = wet corn gluten feed; DDGS2 = dried distillers grains plus solubles (had heating and cooking before fermentation).

${ }^{3}$ Highest SEM is reported. 
mura and colleagues (1994) observed similar apparent $\mathrm{N}$ digestibility $(61.3$ to $65.1 \pm 1.3 \%)$ among different sources of distillers grains with widely variable ADIN values ( 7.8 to $27.9 \%$ of total N). Additionally, Woods and colleagues (2003) observed high intestinal digestibility (97-98\%) of soybean meal samples containing high concentrations of ADIN (6.59 $\pm 1.24 \%$ DM). Therefore, ADIN may not be an accurate indicator of unavailable protein for corn milling co-products because the digestible portion of the RUP $(91.2 \% \mathrm{CP})$ and total-tract digestibility $(95.4 \% \mathrm{CP})$ for DDGS2 were similar to the distillers grains products (DDGS1 and HPDDG) that had much lower concentrations of ADIN.

Digestibility of ADIN in forages is highly variable but averages 30\% (Goering et al., 1972; Yu and Viera, 1977; Weiss et al., 1983). However, Van Soest (1994) proposes $60 \%$ of ADIN in distillers grains is digestible when fed to ruminants. The ADIN may be truly digested, metabolic $\mathrm{N}$ in the feces may be reduced, a portion of the ADIN could be absorbed from the small intestine and excreted in the urine, or a combination of these postulations may explain why ADIN does not reflect protein digestibility in distillers grains (Van Soest, 1994).

The mobile bag technique is most commonly used to measure protein digestibility in the small intestine of ruminant animals (Van der Poel et al., 2005). The low proportions of RUP for germ (16.5\%), bran (20.7\%), and WCGF $(11.5 \%)$ may be attributed to their respective high proportions of fraction $\mathrm{A}$. In addition, lower digestible portions of protein in the small intestine for these nonforage fiber sources ( $66.8 \%$ or germ, $65.8 \%$ for bran, and $51.1 \%$ for WCGF) may be due to their higher rates of degradation and overall lower proportion of protein in these feeds (Kononoff et al., 2007). More protein in these co-products was degraded in the rumen, and the low values of RUP are likely of small practical importance because these co-products are generally not used as sources of bypass protein. Zhao and Cao (2004) reported that in vitro-estimated digestible CP might be highly correlated with the CNCPS protein fractions, which may serve as an alternative method for estimating CP utilization. The estimates of RUP and dRUP for corn distillers grains in the NRC (2001; assuming DMI $=4.1 \%$ of $\mathrm{BW}$ ) are 50.8 and $80.0 \%$, respectively. These default values may be applicable for some samples, such as DDGS2; however, ranges in both RUP and dRUP across samples demonstrate major differences and underline the importance of proper characterization of protein from corn milling co-products. The proportion of TTCPD was high $(>90 \%)$ for all samples, indicating the high degree of digestibility of protein in all corn milling co-products.
The small particle size of all samples used in the in situ procedure may be one factor that results in an overestimation of ruminal degradation (Dewhirst et al., 1994). Even though some particles may be indigestible, they escape through the pores of the Dacron bag and are assumed degraded. In addition, the bags were not corrected for microbial attachment following incubation as suggested by Klopfenstein et al. (2001). Those authors recommend refluxing the in situ bags in neutral detergent solution to remove microbial contamination from the residue. Refluxing with detergent solution is assumed to safely remove microbes attached to residue particles without altering RUP. However, it is generally understood that concentrate feeds have little microbial attachment, and microbial contamination was assumed uniform when comparing differences of co-products (de Boer et al., 1987; von Keyserlingk et al., 1996). Nonetheless, this technique is effective in comparing rumen degradability of feed samples with similar particle size (de Boer et al., 1987; Kononoff et al., 2007).

Phosphorus contents for DDGS1 (0.92\%), WDGS $(0.87 \%)$, and DDGS2 $(0.86 \%)$ were similar to NRC (2001) values. However, P for HPDDG was much lower $(0.35 \%)$ than documented values in the NRC (2001). This difference is likely explained by the addition of condensed corn distillers solubles to DDGS1, WDGS, and DDGS2 but not to HPDDG. The condensed corn distillers solubles was relatively rich in $\mathrm{P}(1.53 \%$; Sasikala-Appukuttan et al., 2008). The high P content of germ was in line with the observations of Ponnampalam et al. (2004) and was expected because of the high concentration of $\mathrm{P}$ in the germ component of the corn kernel. The concentration of sulfur contained in the co-products was generally higher than reported values in the NRC (2001) feed library and is likely due to variation in manufacturing processes among ethanol plants (Spiehs et al., 2002).

Differences were also observed in the AA profile of RUP across co-products. The NRC (2001) default values for Lys and Met in the RUP fraction are 2.24 and $1.82 \% \mathrm{CP}$, respectively. Similar to RUP estimates, NRC (2001) values for Lys and Met are close to those observed in DDGS2, but Lys ranged from $1.86 \% \mathrm{CP}$ for DDGS1 to $3.5 \%$ CP for WCGF, and Met ranged from $1.45 \% \mathrm{CP}$ for bran to $3.17 \% \mathrm{CP}$ for HPDDG. Apparent total-tract AA digestibilities were generally lower in DDGS2, perhaps because of its high ADIN content. Kleinschmit and colleagues (2006) conclude that lower levels (0.44 to $0.52 \% \mathrm{DM}$ ) of ADIN in distillers grains with solubles may improve protein quality and allow increased absorption of essential amino acids. Results of this study reiterate the degree of variation in chemical 
composition associated with different corn milling coproducts produced from the same or different ethanol plants (Belyea et al., 2004).

Physically effective fiber is defined as the portion of dietary fiber particles longer than $1.18 \mathrm{~mm}$ and it is necessary for sustaining the ruminal mat layer, stimulating rumination, and increasing salivation in dairy cattle (Kononoff and Heinrichs, 2003). Particle size distribution was quite different among the 7 corn milling co-products. Physical effectiveness of fiber in any feedstuff is highly correlated to its particle size and fiber content (Grant, 1997). Although co-products are excellent sources of highly digestible fiber, their particle size may not be sufficient to provide peNDF (Mowrey et al., 1999). When NDF was analyzed on particles $>1.18 \mathrm{~mm}$, the values obtained were greater than total sample NDF content. Generally, the distillers grains coproducts evaluated in this study have high proportions of particles $<1.18 \mathrm{~mm}$ and corresponding low values for peNDF. However, an exception to this observation is DDGS2, which had $60.1 \%$ of particles $<1.18 \mathrm{~mm}$ compared with $94.2 \%$ for DDGS1, $87.8 \%$ for HPDDG, and $82.2 \%$ for WDGS, and had $17.7 \%$ peNDF compared with $1.60 \%$ for DDGS1, $6.28 \%$ for HPDDG, and $7.63 \%$ peNDF for WDGS. The DDGS2 co-product had sizeable clusters of solubles that could not be easily broken, which may have distorted particle size distribution and inflated peNDF measurements. Germ (40.4\%), WCGF (39.3\%), and bran (37.1\%) had similar and much lower proportions of particles $<1.18 \mathrm{~mm}$. Therefore, the peNDF content for these co-products was much higher than observed with the distillers grains co-products (21.1, 25.9, and 17.4 peNDF for germ, WCGF, and bran, respectively). Allen and Grant (2000) reported a higher peNDF value $(32.0 \%)$ and a higher NDF content $(43.9 \%)$ for wet corn gluten feed than was determined on WCGF in this study (25.9 and 36.9\%). These nonforage fiber sources may be included in diets for lactating dairy cows as highly digestible energy sources without the great risk of ruminal acidosis associated with rapidly fermented starch sources (Mowrey et al., 1999; Boddugari et al., 2001). Adequate amounts of peNDF in dairy rations are important to prevent ruminal acidosis, which may depress intake, milk and milk fat production, and fiber digestion (NRC, 2001).

The FA profile (\% TFA) of corn grain $(4.25 \% \mathrm{TFA})$ is 0.04\% C14:0, 13.6\% C16:0, 1.8\% C18:0, 23.2\% C18:1 cis, $57.6 \% \mathrm{C} 18: 2,1.8 \mathrm{C} 18: 3$, and 1.3\% other lipid (Duckett et al., 2002). Generally, the FA profiles of the co-products were similar to FA profiles reported for corn by Duckett and colleagues (2002) and DDGS reported by Leonardi et al. (2005). Because of a high concentration of lipid in the germ fraction of the corn kernel (Murthy et al., 2008), the germ co-product was expected to have more total FA than other co-products.

In vitro gas production resulting from microbial fermentation may be an accurate indication of feed digestibility in ruminants (Schofield et al., 1994). The asymptote $(a)$, as well as the rate $(b)$ of IVGP was observed to be higher for germ and bran co-products compared with other co-products. These results are likely a function of the high concentrations of sugars and starch found in germ $(9.2 \%$ and $28.8 \%)$ and bran (5.1\% and $32.0 \%)$. Sugars and starches from processed cereal grains are rapidly fermented by ruminal microbes (Sniffen et al., 1992). Nevertheless, the remaining co-products had relatively high levels of IVGP, which suggests they are rich sources of highly fermentable fiber. Because fat may negatively affect the ability of ruminal microbes to attach to and digest fibrous particles, potential IVGP may be greater than observed in this study if fat is removed before fermentation. In addition, germ and bran co-products were observed to have larger particles than other co-products. Research conducted by Udén (1992) suggested that in vitro lag time was shorter as forage particle size was reduced. Smaller particle size increases surface area available for microbial attachment, which may reduce lag time and enhance digestibility (Kitessa et al., 1999). Results of the current study demonstrate that corn milling co-products differ in the composition of carbohydrate, and these differences also exist in the pattern of ruminal fermentation and nutrient availability.

\section{CONCLUSIONS}

Ration formulation software programs are modified to include sub-models that account for differences in various chemical compositions, rates of degradation, and nutrient availabilities of feedstuffs. Extensive research has determined chemical composition and nutrient availability information for traditional corn milling co-products, but novel co-products have not yet been readily characterized. This research demonstrates the large variation present across different types of corn milling co-products. Crude protein was highest for HPDDG (45.4\%) and lowest for bran (12.7\%), RUP was highest for DDGS2 $(56.3 \% \mathrm{CP})$ and lowest for WCGF (11.5\% CP), dRUP was highest for HPDDG (97.7\% $\mathrm{CP})$ and lowest for WCGF (51.1\% CP), and TTDCP was greater than $90 \% \mathrm{CP}$ for all co-products. The NRC (1996) assumes 80\% RUP digestibility in the small intestine for all feedstuffs, whereas the NRC (2001) allows for variable intestinal digestibility of RUP, which ranges from 50 to $100 \%$ across feedstuffs. Recently determined values as inputs for chemical composition and 
nutrient availability in nutrition models may be more valuable than "book" values when formulating livestock rations. Furthermore, this research demonstrated the importance of understanding the chemical composition of similar feed products originating from different production facilities. When the accuracy of these inputs improves, rations can be formulated more precisely to meet animal requirements and models are better able to predict performance based on available metabolizable energy and protein.

\section{ACKNOWLEDGMENTS}

The authors thank the personnel at the University of Nebraska Ruminant Nutrition and Metabolism Area (Lincoln, NE) for laboratory assistance and care of the experimental animals during the experiment. We also thank Mario Chizzotti (Texas A\&M University, College Station) for his assistance on the IVGP data collection.

\section{REFERENCES}

Allen, D. M., and R. J. Grant. 2000. Interactions between forage and wet corn gluten feed as sources of fiber in diets for lactating dairy cows. J. Dairy Sci. 83:322-331.

Anderson, J. L., D. J. Shingoethe, K. F. Kalscheur, and A. R. Hippen. 2006. Evaluation of dried and wet distillers grains included at two concentrations in the diets of lactating dairy cows. J. Dairy Sci. 89:3133-3142.

AOAC. 1996. Official Methods of Analysis. 16th ed. Association of Official Analytical Chemists, Arlington, VA.

AOAC. 2000. Official Methods of Analysis. 17th ed. Association of Official Analytical Chemists, Arlington, VA.

Bechtel, H. E., F. W. Atkeson, and J. S. Hughes. 1943. Brown silage from atlas sorgo-chemical composition and apparent digestibility as determined by feeding to dairy cows. J. Anim. Sci. 2:295-303.

Bechtel, H. E., A. O. Shaw, and F. W. Atkenson. 1945. Brown alfalfa hay: Its chemical composition and nutritive value in dairy rations. J. Dairy Sci. 28:35-48.

Belyea, R. L., K. D. Rausch, and M. E. Tumbleson. 2004. Composition of corn and distillers dried grains with solubles from dry grind ethanol processing. Bioresour. Technol. 94:293-298.

Boddugari, K., R. J. Grant, R. Stock, and M. Lewis. 2001. Maximal replacement of forage and concentrate with a new wet corn milling product for lactating dairy cows. J. Dairy Sci. 84:873-884.

Boucher, S. E., S. Calsamiglia, C. M. Parsons, M. D. Stern, M. Ruiz Moreno, M. Vázquez-Añón, and C. G. Schwab. 2009. In vitro digestibility of individual amino acids in rumen-undegraded protein: The modified three-step procedure and the immobilized digestive enzyme assay. J. Dairy Sci. 92:3939-3950.

Bratzler, J. W., E. Keck Jr., and R. R. Yoerger. 1960. Effect of temperature upon the nutritive value of artificially dried hay. J. Anim. Sci. 19:1186-1189.

Corredor, D. Y., S. R. Bean, T. Schober, and D. Wang. 2006. Effect of decorticating sorghum on ethanol production and composition of DDGS. Cereal Chem. 83:17-21.

de Boer, G., J. J. Murphy, and J. J. Kennelly. 1987. Mobile nylon bag for estimating intestinal availability of rumen undegradable protein. J. Dairy Sci. 70:977-982.

Dewhirst, R. J., D. Hepper, and A. J. F. Webster. 1994. Comparison of in sacco and in vitro techniques for estimating the rate and extent of rumen fermentation of a range of dietary ingredients. Anim. Feed Sci. Technol. 51:211.
Duckett, S. K., J. G. Andrae, and F. N. Owens. 2002. Effect of high-oil corn or added corn oil on ruminal biohydrogenation of fatty acids and conjugated linoleic acid formation in beef steers fed finishing diets. J. Anim. Sci. 80:3353-3360.

Firkins, J. L., L. L. Berger, G. C. Fahey Jr., and N. R. Merchen. 1984. Ruminal nitrogen degradability and escape of wet and dry distillers grains and wet and dry corn gluten feeds. J. Dairy Sci. 67:1936-1944.

Fox, D. G., L. O. Tedeschi, T. P. Tylutki, J. B. Russell, M. E. Van Amburgh, L. E. Chase, A. N. Pell, and T. R. Overton. 2004. The Cornell Net Carbohydrate and Protein System model for evaluating herd nutrition and nutrient excretion. Anim. Feed Sci. Technol. 112:29-78.

Goering, H. K., C. H. Gordon, R. W. Hemken, D. R. Waldo, P. J. Van Soest, and L. W. Smith. 1972. Analytical estimates of nitrogen digestibility in heat damaged-forages. J. Dairy Sci. 55:12751280 .

Goering, H. K., P. J. Van Soest, and R. W. Hemken. 1973. Relative susceptibility of forages to heat damage as affected by moisture, temperature, and pH. J. Dairy Sci. 56:137-143.

Grant, R. J. 1997. Interactions among forages and nonforage fiber sources . J. Dairy Sci. 80:1438-1446.

Hall, M. B., W. H. Hoover, J. P. Jennings, and T. K. Miller Webster. 1999. A method for partitioning neutral detergent soluble carbohydrates. J. Sci. Food Agric. 79:2081.

Hill, D. L., and C. H. Noller. 1963. The apparent digestibility of protein in low moisture silages. J. Anim. Sci. 22:850.

Janicek, B. N., P. J. Kononoff, A. M. Gehman, K. Karges, and M. L. Gibson. 2007. Short communication: Effect of increasing levels of corn bran on milk yield and composition. J. Dairy Sci. 90:43134316.

Kitessa, S., P. C. Flinn, and G. G. Irish. 1999. Comparison of methods used to predict the in vivo digestibility of feeds in ruminants. Aust. J. Agric. Res. 50:825-841.

Kleinschmit, D. H., J. L. Anderson, D. J. Schingoethe, K. F. Kalscheur, and A. R. Hippen. 2007. Ruminal and intestinal degradability of distillers grains plus solubles varies by source. J. Dairy Sci. 90:2909-2918

Kleinschmit, D. H., D. J. Schingoethe, K. F. Kalscheur, and A. R. Hippen. 2006. Evaluation of various sources of corn dried distillers grains plus solubles for lactating dairy cattle. J. Dairy Sci. 89:4784-4794.

Klopfenstein, T. J. 1996. Distillers grains as an energy source and effect of drying on protein availability. Anim. Feed Sci. Technol. 60:201-207.

Klopfenstein, T. J., R. A. Mass, K. W. Creighton, and H. H. Patterson. 2001. Estimating forage protein degradation in the rumen. J. Anim. Sci. 79(E. Suppl.):E208-E217.

Kononoff, P. J., and A. J. Heinrichs. 2003. The effect of reducing alfalfa haylage particle size on cows in early lactation. J. Dairy Sci. $86: 1445-1457$.

Kononoff, P. J., S. K. Ivan, and T. J. Klopfenstein. 2007. Estimation of the proportion of feed protein digested in the small intestine of cattle consuming wet corn gluten feed. J. Dairy Sci. 90:23772385

Kononoff, P. J., S. K. Ivan, W. Matzke, R. J. Grant, R. A. Stock, and T. J. Klopfenstein. 2006. Milk production of dairy cows fed wet corn gluten feed during the dry period and lactation. J. Dairy Sci. 89:2608-2617.

Leonardi, C., S. Bertics, and L. E. Armentano. 2005. Effect of increasing oil from distillers grains or corn oil on lactation performance. J. Dairy Sci. 88:2820-2827.

Lewis, A. J., P. J. Holden, R. C. Ewan, and D. R. Zimmerman. 1976. An automated fluorometric method for the measurement of tryptophan in plasma. J. Agric. Food Chem. 24:1081.

Licitra, G., T. M. Hernandez, and P. J. Van Soest. 1996. Standardization of procedures for nitrogen fractionation of ruminant feeds. Anim. Feed Sci. Technol. 57:347-358.

Mertens, D. R. 1997. Creating a system for meeting the fiber requirements of dairy cows. J. Dairy Sci. 80:1463-1481. 
Miller, L. G., D. C. Clanton, L. F. Nelson, and O. E. Hochne. 1967. Nutritive value of hay baled at various moisture contents. J. Anim. Sci. 26:1369-1373.

Mowrey, A., M. R. Ellersieck, and J. N. Spain. 1999. Effect of fibrous by-products on production and ruminal fermentation in lactating dairy cows. J. Dairy Sci. 82:2709-2715.

Murthy, G. S., E. D. Sall, S. G. Metz, G. Foster, and V. Singh. 2008. Evaluation of a dry corn fractionation process for ethanol production with different hybrids. Ind. Crops Prod. In press.

Murthy, G. S., V. Singh, D. B. Johnston, K. D. Rausch, and M. E. Tumbleson. 2006. Evaluation and strategies to improve fermentation characteristics of modified dry- grind corn processes. Cereal Chem. 83:455-459.

Nakamura, T., T. J. Klopfenstein, and R. A. Britton. 1994. Evaluation of acid detergent insoluble nitrogen as an indicator of protein quality in nonforage proteins. J. Anim. Sci. 72:1043-1048.

NRC. 1996. Nutrient Requirements of Beef Cattle. 7th ed. National Academy Press, Washington, DC.

NRC. 2001. Nutrient Requirements of Dairy Cattle. 7th rev. ed. National Academy Press, Washington, DC.

Pell, A. N., and P. Schofield. 1993. Computerized monitoring of gas production to measure forage digestion in vitro. J. Dairy Sci. 76:1063-1073.

Ponnampalam, E., D. B. Steele, D. Burgdorf, and D. McCalla. 2004. Effect of germ and fiber removal on production of ethanol from corn. Appl. Biochem. Biotechnol. 115:837-842.

Roe, M. B., and C. J. Sniffen. 1990. Techniques for measuring protein fractions in feedstuffs. Pages 81-88 in Proc. Cornell Nutr. Conf., Rochester, NY, Cornell University, Ithaca, NY.

Russell, J. B., J. D. O'Connor, D. G. Fox, P. J. Van Soest, and C. J. Sniffen. 1992. A net carbohydrate and protein system for evaluating cattle diets: I. Ruminal fermentation. J. Anim. Sci. 70:3551-3561.

Sasikala-Appukuttan, A. K., D. J. Shingoethe, A. R. Hippen, K. F. Kalscheur, K. Karges, and M. L. Gibson. 2008. The feeding value of corn distillers solubles for lactating dairy cows. J. Dairy Sci. 91:279-287.

Schofield, P., R. E. Pitt, and A. N. Pell. 1994. Kinetics of fiber digestion from in vitro fiber digestion. J. Anim. Sci. 72:2980-2991.

Schwab, C. G., T. P. Tylutki, R. S. Ordway, C. Sheaffer, and M. D. Stern. 2003. Characterization of protein in feeds. J. Dairy Sci. 86(E. Suppl.):E88-E103.

Sirois, P. K., M. J. Reuter, C. M. Laughlin, and P. J. Lockwood. 1994. A method for determining macro and micro elements in forages and feeds by inductively coupled plasma atomic emission spectrometry. Spectroscopist 3:6-9.

Sniffen, C. J., J. D. O'Conner, P. J. Van Soest, D. G. Fox, and J. B. Russell. 1992. A net carbohydrate and protein system for evaluating cattle diets: II. Carbohydrate and protein availability. J. Anim. Sci. 70:3562-3577.

Spiehs, M. J., M. H. Whiteny, and G. C. Shurson. 2002. Nutrient database for distillers dried grains with solubles produced from new ethanol plants in Minnesota and South Dakota. J. Anim. Sci. 80:2639-2645.

Sukhija, P. S., and D. L. Palmquist. 1988. Rapid method for determination of total fatty acid content and composition of feedstuffs and feces. J. Agric. Food Chem. 36:1202-1206.
Tedeschi, L. O., W. Chalupa, E. Janczewski, D. G. Fox, C. J. Sniffen, R. Munson, P. J. Kononoff, and R. C. Boston. 2008. Evaluation and application of the CPM Dairy nutrition model. J. Agric. Sci. 146:171-182.

Udén, P. 1992. The influence of leaf and stem particle size in vitro and of sample size in sacco on neutral detergent fiber fermentation kinetics. Anim. Feed Sci. Technol. 37:85.

Van der Poel, A. F. B., E. Prestlokken, and J. O. Goelema. 2005. Feed processing: effects on nutrient degradation and digestibility. Pages 627-661 in Quantitative Aspects of Ruminant Digestion and Metabolism. 2nd ed. J. Dijkstra, J. M. Forbes, and J. France, eds. CABI Publishing, New York, NY.

Van Soest, P. J. 1965. Use of detergents in analysis of fibrous feeds. III. Study of effects of heating and drying on yields of fiber and lignin in forages. J. AOAC 48:785.

Van Soest, P. J. 1994. Nutritional Ecology of the Ruminant. 2nd ed. Comstock Publishing Associates, Ithaca, NY.

Van Soest, P. J., J. B. Robertson, and B. A. Lewis. 1991. Methods for dietary fiber, neutral detergent fiber, and non-starch polysaccharides in relation to animal nutrition. J. Dairy Sci. 74:3583-3597.

VanBaale, M. J., J. E. Shirley, E. C. Titgemeyer, A. F. Park, M. J. Meyer, R. U. Lindquist, and R. T. Ethington. 2001. Evaluation of wet corn gluten feed in diets for lactating dairy cows. J. Dairy Sci. 84:2478-2485.

Vanzant, E. S., R. C. Cochran, and E. C. Titgemeyer. 1998. Standardization of in situ techniques for ruminant feedstuff evaluation. J. Anim. Sci. 76:2717-2729.

von Keyserlingk, M. A. G., M. L. Swift, R. Puchala, and J. A. Shelford. 1996. Degradability characteristics of dry matter and crude protein of forages in ruminants. Anim. Feed Sci. Technol. 57:291-311.

Wang, P., V. Singh, H. Xue, D. B. Johnston, K. D. Rausch, and M. E. Tumbleson. 2007. Comparison of raw starch hydrolyzing enzyme with conventional liquefaction and saccharification enzymes in dry-grind corn processing. Cereal Chem. 84:10-14.

Weiss, W. P., H. R. Conrad, and W. L. Shockey. 1983. Predicting digestible protein using acid detergent insoluble nitrogen. J. Dairy Sci. 66(Suppl. 1):192. (Abstr.)

Weiss, W. P., H. R. Conrad, and W. L. Shockey. 1986. Digestibility of nitrogen in heat-damaged alfalfa. J. Dairy Sci. 69:2658-2670.

Wieringa, G. W., S. Schukking, D. Kappelle, and S. J. Dehaan. 1961. The influence of heating on silage fermentation and quality. Neth. J. Agric. Sci. 9:210.

Woods, V. B., A. P. Moloney, S. Calsamiglia, and F. P. O'Mara. 2003. The nutritive value of concentrate feedstuffs for ruminant animals part III: small intestinal digestibility as measured by in vitro or mobile bag techniques. Anim. Feed Sci. Technol. 110:145-157.

Yu, Y., and J. W. Thomas. 1975. Temperature, insoluble nitrogen, and animal response to haylage from different vertical areas in the silo. J. Anim. Sci. 41:915-920.

Yu, Y., and D. M. Viera. 1977. Effect of artificial heating of alfalfa haylage on chemical composition and sheep performance. J. Anim. Sci. 44:1112-1118.

Zhao, G. Y., and J. E. Cao. 2004. Relationship between the in vitroestimated utilizable crude protein and the cornell net carbohydrate and protein system crude protein fractions in feeds for ruminants. J. Anim. Physiol. Anim. Nutr. (Berl.) 88:301-310. 